\title{
Fatty acid composition of phospholipids from platelets and erythrocytes in multiple sclerosis
}

\author{
S. GUL, A. D. SMITH, R. H. S. THOMPSON, H. PAYLING WRIGHT, AND \\ K. J. ZILKHA
}

From the Courtauld Institute of Biochemistry, Middlesex Hospital Medical School, Department of Pharmacology, Royal College of Surgeons, and The National Hospital, Queen Square, London

SUMMARY The fatty acid composition of the phospholipids of red blood cells and blood platelets has been investigated in multiple sclerosis patients and in normal individuals. The variation in the platelet phospholipid fatty acid pattern in normals has been measured for the first time and has been shown to be small. The relative level of linoleate, expressed as a percentage of the five main fatty acids, was found to be significantly lower in the multiple sclerosis patients than in healthy individuals, both in the red cells and platelets. A highly significant correlation was found between serum linoleate and both platelet and red cell linoleate.

Estimations of linoleate by gas chromatography, or of cholesteryl linoleate by thin-layer chromatography, have shown that the level of linoleate in the serum is significantly reduced in patients with 'active' multiple sclerosis (Baker, Thompson, and Zilkha, 1964, 1966; Baker, Sanders, Thompson, and Zilkha, 1965; Sanders, Thompson, Wright, and Zilkha, 1968). Several groups of workers, but not all, have also found the level of total cholesteryl esters in the serum to be slightly reduced, again particularly in patients with clinical exacerbations of the disease (Baker et al., 1965; Sěrcl, Kovařík, and Jícha, 1961; Cendrowski, Szajbel, Waskiewicz, and Niedzielska, 1968).

Increased adhesiveness of the blood platelets from patients with multiple sclerosis has been described by several groups (Nathanson and Savitsky, 1952; Fog, Kristensen, and Helweg-Larsen, 1955; Caspary, Prineas, Miller, and Field, 1965; Wright, Thompson, and Zilkha, 1965; Millar, Merrett, and Dalby, 1966; Millac, 1967). Furthermore, Sanders et al. (1968) have shown that in this disease there is a highly significant correlation $(P<0.001)$ between serum cholesteryl linoleate levels and platelet adhesiveness. They concluded, however, that the observed changes in these two parameters are likely each to be due to some other process taking place in this disease, rather than the one causing changes in the other.

Turning to the red blood cells, Plum and Fog (1959) showed that the mean erythrocyte diameter was increased in multiple sclerosis, a finding con- firmed by Prineas (1968), who found that the in crease correlated with the activity of the disease. $\mathbb{D}$ o The osmotic fragility of red blood cells in multiple요 sclerosis has also been studied. Laszlo in 1964 first reported a highly significant increase in osmotic fragility. Caspary, Sewell, and Field (1967) have confirmed Laszlo's finding, and in this case also they were able to correlate the extent of the chang with the activity of the disease.

Because of these various findings, it was decided to carry out a study of the fatty acid composition of platelets and erythrocytes from patients with multiple sclerosis, and the present communication describes our findings for the total phospholipid fraction obtained from these blood elements.

\section{MATERIALS AND METHODS}

MATERIALS Solvents were May \& Baker reagent grade and were, with the exception of diethyl ether, redistilled before use. Silicic acid was Mallinckrodt Analytical Reagent 100 mesh. It was washed and activated as described by Rouser, O'Brien, and Heller (1961).

PREPARATION OF PLATELETS Fifteen to twenty millilitres of blood were drawn from the antecubital vein into a plastic syringe containing $3.8 \%$ trisodium citrate $(0.1$ $\mathrm{ml} . / \mathrm{ml}$. blood), and transferred into plastic tubes or siliconized glass bottles.

The blood was centrifuged for $15 \mathrm{~min}$ at $200 \mathrm{~g}$ and the supernatant platelet-rich plasma transferred to siliconized centrifuge tubes, taking care not to disturb the buffy layer; $0.1 \mathrm{ml}$ was withdrawn for counting, and the remainder centrifuged for four minutes at $21,000 \mathrm{~g}$ at 
$0^{\circ}$. The supernatant plasma was decanted and the pellet washed three times with $3.8 \%$ trisodium citrate using a volume equal to the plasma.

PLATELET COUNT The count was estimated by the direct wet method using Rees-Ecker diluting fluid as modified by Wright (1941). Red cell counts, caried out on the platelet-rich plasma, showed that contamination of the platelets was not likely to have interfered significantly with our analytical findings.

PLATELET ADHESIVENESS This was measured by the rotating bulb technique (Wright, 1941).

RED CELL PREPARATION $0.1 \mathrm{ml}$. of the packed red cells was taken and washed three times with $10 \mathrm{ml} .3 .8 \%$ trisodium citrate. The pellet from the final washing was used for extraction of lipid.

LIPID EXTRACTION The platelet or red cell pellet was homogenized for two minutes in an MSE top-drive blender using $12 \mathrm{ml}$. chloroform: ethanol (2:1), through which nitrogen had been bubtled previously. The extract was filtered through Whatman glass fibre filter paper and then washed with $0.1 \mathrm{M} \mathrm{KCl}$ (Folch, Lees, and SloaneStanley, 1957). A single extraction was considered sufficient, as no fatty acid could be detected in hydrolysates obtained from a second extraction. The chloroform:methanol was removed in a stream of nitrogen and the extract dissolved in $2 \mathrm{ml}$. chloroform:hexane:ether $(2: 1: 1)$ for separation of the phospholipids.

PHOSPHOLIPID SEPARATION The method used was essentially that of Hornstein, Crowe, and Ruck (1967).
This is a batch method which is convenient and rapid, and because the time of handling the lipid extract is short, losses of unsaturated fatty acid are minimized. In a typical experiment, $200 \mathrm{mg}$ silicic acid were measured into a stoppered tube, the lipid extract in chloroform: hexane:ether added, the contents mixed on a Vortex mixer for one minuts and allowed to stand for two minutes. The tube was then centrifuged for two minutes at $400 \mathrm{~g}$, the supernatant removed, and the silicic acid pellet washed twice with $3 \mathrm{ml}$. chloroform:hexane:ether. At this stage $97 \cdot 1 \mu \mathrm{g}$ heneicosanoic $\left(C_{21}\right)$ acid methyl ester were added as an internal standard.

FORMATION OF METHYL ESTERS The methyl esters of the fatty acids were formed directly by methanolysis of the phospholipids on the silicic acid using $1 \mathrm{ml} .0 \cdot 3 \mathrm{~N}$ sodium methoxide as described by Hornstein et al. (1967), except that a temperature of $45^{\circ} \mathrm{C}$ was used for one hour. Phosphorus was estimated by the method of Rouser, Siakotos, and Fleischer (1966) on the filtrate after methyl ester extraction with hexane.

GAS CHROMATOGRAPHY Fatty acid methyl esters were run on $20 \%$ di-ethylene glycol succinate on chromosorb W 80-100 mesh at $170^{\circ}$ using a Perkin-Elmer F11 gas chromatograph.

\section{RESULTS}

The results are shown in the Table. The mean level of platelet phospholipid linoleate (expressed as a percentage of the total fatty acids) is significantly lower in the patients with multiple sclerosis than it

TABLE

FATTY ACID COMPOSITION OF PLATELET AND RED CELL PHOSPHOLIPIDS

\begin{tabular}{|c|c|c|c|c|c|c|c|c|}
\hline \multirow[b]{3}{*}{ Cases (no.) } & \multicolumn{4}{|c|}{ Platelet phospholipid fatty acids } & \multicolumn{4}{|c|}{ Red blood cell phospholipid fatty acids } \\
\hline & \multicolumn{2}{|c|}{$\%$ Total fatty acids* } & \multicolumn{2}{|c|}{ Mole/mole $P$} & \multicolumn{2}{|c|}{$\%$ Total fatty acids* } & \multicolumn{2}{|c|}{ Mole/mole $P$} \\
\hline & $\begin{array}{c}\text { Control } \\
14\end{array}$ & $\begin{array}{c}M . S . \\
20\end{array}$ & $\begin{array}{c}\text { Control } \\
14\end{array}$ & $\begin{array}{c}M . S . \\
20\end{array}$ & $\begin{array}{c}\text { Control } \\
11\end{array}$ & $\begin{array}{c}M . S . \\
10\end{array}$ & $\begin{array}{c}\text { Control } \\
11\end{array}$ & $\begin{array}{c}M . S . \\
10\end{array}$ \\
\hline $16: 0$ & $\begin{array}{c}19.2 \\
\pm 0.37\end{array}$ & $\begin{array}{r}18 \cdot 8 \\
\pm 03 \cdot 1\end{array}$ & $\begin{array}{c}0.27 \\
\pm 0.007\end{array}$ & $\begin{array}{c}0.25 \\
\pm 0.013\end{array}$ & $\begin{array}{c}26.1 \\
\pm 0.48\end{array}$ & $\begin{array}{c}26.9 \\
\pm 0.36\end{array}$ & $\begin{array}{c}0.32 \\
\pm 0.006\end{array}$ & $\begin{array}{c}0.36 \\
\pm 0.016\end{array}$ \\
\hline $18: 0$ & $\begin{array}{c}24 \cdot 5 \\
\pm 0.37\end{array}$ & $\begin{array}{r}24.4 \\
\pm 0.31\end{array}$ & $\begin{array}{c}0.27 \\
\pm 0.005\end{array}$ & $\begin{array}{r}0.29 \\
\pm 0.01\end{array}$ & $\begin{array}{c}22 \cdot 3 \\
\pm 0.27\end{array}$ & $\begin{array}{c}21.8 \\
\pm 0.28\end{array}$ & $\begin{array}{c}0.25 \\
+0.006\end{array}$ & $\begin{array}{r}0.27 \\
\pm 0.01\end{array}$ \\
\hline $18: 1$ & $\begin{array}{c}21.0 \\
\pm 0.27\end{array}$ & $\begin{array}{c}21.4 \\
\pm 0.27\end{array}$ & $\begin{array}{c}0.24 \\
\pm 0.006\end{array}$ & $\begin{array}{c}0.26 \\
\pm 0.009\end{array}$ & $\begin{array}{c}20.1 \\
\pm 0.27\end{array}$ & $\begin{array}{c}21.4 \\
\pm 0.32\end{array}$ & $\begin{array}{c}0.23 \\
\pm 0.005\end{array}$ & $\begin{array}{r}0.26 \\
\pm 0.01\end{array}$ \\
\hline $18: 2$ & $\begin{array}{c}6 \cdot 3 \\
\pm 0.27\end{array}$ & $\begin{array}{c}4.9 \\
+0.12\end{array}$ & $\begin{array}{c}0.07 \\
\pm 0.032\end{array}$ & $\begin{array}{c}0.06 \\
\pm 0.003\end{array}$ & $\begin{array}{c}14.0 \\
\pm 0.42\end{array}$ & $\begin{array}{c}11.0 \\
\pm 0.44\end{array}$ & $\begin{array}{c}0.16 \\
\pm 0.006\end{array}$ & $\begin{array}{r}0.14 \\
\pm 0.08\end{array}$ \\
\hline $20: 4$ & $\begin{array}{c}29 \cdot 1 \\
\pm 0.62\end{array}$ & $\begin{array}{c}30.5 \\
\pm 0.62\end{array}$ & $\begin{array}{r}0.31 \\
\pm 0.01\end{array}$ & $\begin{array}{r}0.34 \\
\pm 0.13\end{array}$ & $\begin{array}{c}17 \cdot 4 \\
\pm 0.60\end{array}$ & $\begin{array}{c}18.8 \\
\pm 0.44\end{array}$ & $\begin{array}{c}0.18 \\
\pm 0.009\end{array}$ & $\begin{array}{r}0.22 \\
\pm 0.01\end{array}$ \\
\hline Total & & & $1 \cdot 13$ & $1 \cdot 20$ & & & $1 \cdot 14$ & $1 \cdot 25$ \\
\hline
\end{tabular}

* Only the five fatty acids listed were totalled. Controls and patients were reasonably matched for age. No sex differences were apparent but control and patient values are composed of similar numbers of each sex.

$\%$ Platelet linoleate controls v. M.S. $P<0.001$

$\%$ Red blood cell linoleate controls v. M.S. $P<0.001$.

Red blood cell linoleate (mole/mole P) controls v. M.S. $P<0.05$. 
is in the healthy individuals. The mean level of red blood cell phospholipid linoleate, also, is significantly lower in the patients than in the normals, if it is expressed as a percentage of the total fatty acids. There is no significant difference in any other fatty acid between patients and healthy individuals.

When the results are expressed as mole fatty acid/ mole phosphorus, as shown in the Table, the difference in linoleate levels between normals and patients is no longer apparent for platelets, while for red blood cells the significance is decreased $(P<0.05)$. For both platelets and red cells the mean level of linoleate is lower, while the mean level of every other fatty acid is higher, in patients as compared with normals. This imbalance accounts for the significant difference found when the results are expressed as percentages.

Observations were made on a number of patients with neurological diseases other than multiple sclerosis. These neurological 'controls' represented a very varied range of diseases, and are, therefore, not presented as a group in the Table. In some of the conditions studied the percentage of linoleate in the phospholipids of either the platelets or the red cells was low, although in other conditions it was normal. Since, however, in most cases we have so far studied only one example of each condition, we can conclude little from these observations.

The total fatty acid yield in moles/mole $P$ lies between $1 \cdot 13$ and $1 \cdot 25$. This may at first sight appear low since the phosphatidyl cholines, ethanolamines, and serines, the di-acyl components of which comprise the major part of this fraction, should yield 2 mole fatty acid/mole $P$. The presence of sphingomyelins and plasmalogens containing only one fatty acid, will reduce the fatty acid: phosphorus ratio, but not, from theoretical calculations, to the extent found. In this connection, it is of interest that Ways and Hanahan (1964), in a thorough study of extraction methods, found the mean ester :phosphorus ratio (the ester determined spectrophotometrically in the intact phospholipids) to be as low as 1.40. Allowing for losses of fatty acids on saponification and extraction therefore, our values appear reasonable.

Platelet ADHESIVeness Platelet adhesiveness measurements were made on most of the patients on whose blood the platelet lipid analysis was done. In agreement with earlier results, the values for platelet adhesiveness in the patients with multiple sclerosis were greater than for normals.

CORRELATION BETWEEN THE LEVELS OF SERUM, PLATELET, AND RED CELL LINOLEATE In some instances, determinations of serum total linoleate, platelet linoleate, and red cell linoleate have been made on the same blood sample, and the correlations of our findings are shown in Figs. 1 and 2.

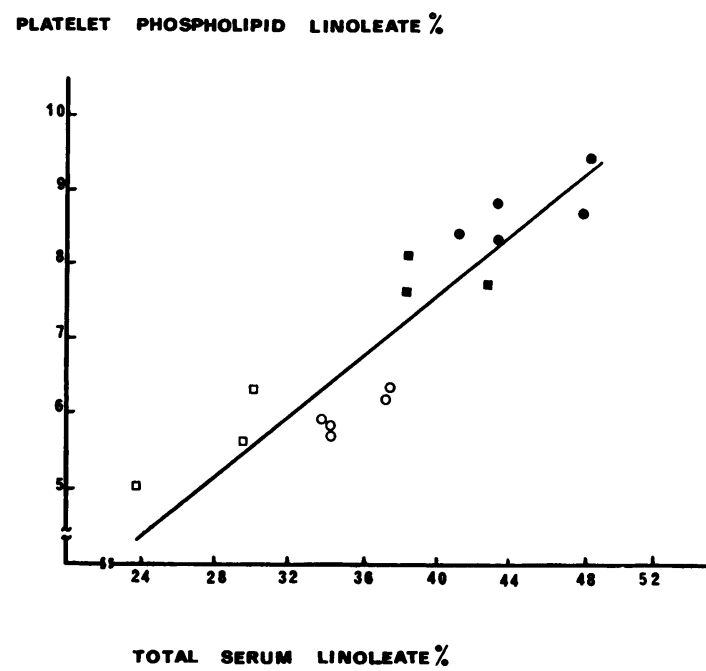

FIG. 1. Relationship between serum linoleate and platelet linoleate. $\bigcirc=$ healthy individuals before oil; $\bullet=$ healthy individuals after oil; $\square=$ M.S. before oil; $\square=$ M.S. after oil.

Eight of the blood samples giving rise to points in these figures were obtained during experiments designed to observe the effect on the lipids in serum and in blood cells of five daily doses of $45 \mathrm{~g}$ sunflower seed oil (which is rich in linoleate). These, and related, experiments will be fully reported later, but the lipid levels obtained in them have been included here in order to increase the number of observations and to extend the range of linoleate levels. The inclusion of values obtained after five days on the oil reveals that a highly significant correlation $(P<0.001)$ exists between the level of serum linoleate and the levels of both platelet and red cell linoleate. If these values are omitted, a correlation is still apparent, but, because of the smaller number of observations, it is of lower statistical significance $(P<0.05)$.

\section{DISCUSSION}

The work described here offers some evidence for low linoleate levels in platelet and red blood cell phospholipids in multiple sclerosis, though this appears to be a relative rather than an absolute deficiency. Further work is needed to determine 
RED CELL PHOSPHOUPID LINOLEATE \%

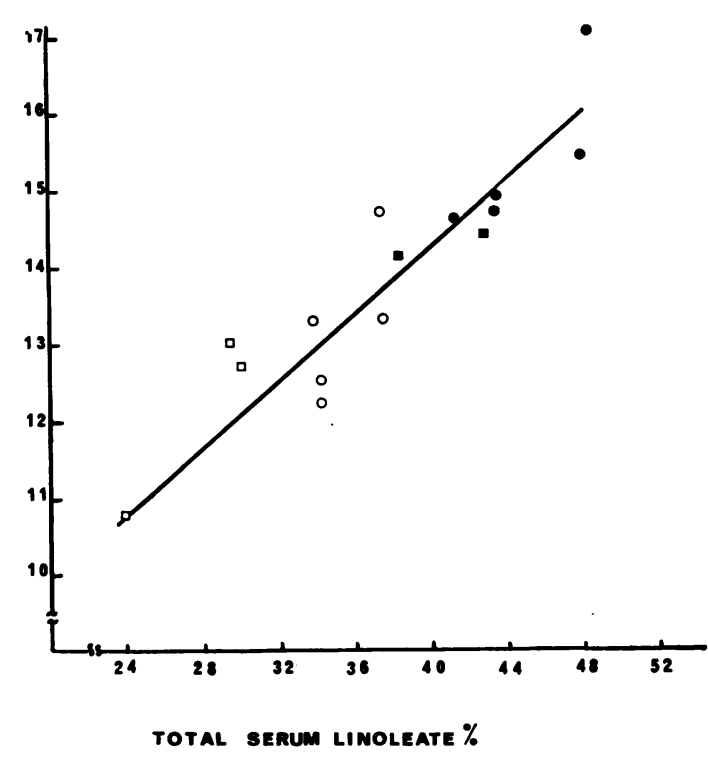

FIG. 2. Relationship between serum linoleate and red cell linoleate. $O=$ healthy individuals before oil; $O=$ healthy individuals after oil; $\square=$ M.S. before oil; $\square=M$.S. after oil.

whether this results from the altered levels of serum fatty acids found in this disease.

No report on the pattern of fatty acids in the total phospholipid fraction of blood platelets has been found. Previous authors (Marcus, Ullman, and Safier, 1969; Cohen and Derksen, 1969) have used fractionation procedures yielding individual phospholipids before analysis of the fatty acid pattern. In our work, as we have taken the total phospholipid fraction, it has been possible to carry out the analysis on only $20 \mathrm{ml}$. blood, thus permitting for the first time a study of a sufficient number of individuals to allow an estimate of the variation in the normal, and a meaningful statistical comparison between controls and pathological cases.

Our values for the fatty acids of red blood cells are within the range previously published (Ways and Hanahan, 1964; Van Deenen and de Gier, 1964a).

It has previously been shown that a highly significant correlation exists between serum linoleate and platelet adhesiveness in patients with multiple sclerosis (Wright et al., 1965). Our present results show a highly significant correlation between serum linoleate and platelet linoleate. It might therefore be thought that a correlation should exist between platelet linoleate level and platelet adhesiveness. Such a correlation was, in fact, not found in the present study, possibly because the experimental variation in the estimations was too great to reveal a correlation between these two measurements with this comparatively small number of patients.

The relatively low linoleate in the red cells of patients with multiple sclerosis is of interest in connection with the increased erythrocyte fragility in this disease, though it is necessary to be cautious in interpreting the result. A lowered red cell linoleate has been found in a number of pathological conditions (Van Deenen and de Gier, 1964b), and the possibility referred to by these authors that the results may be due to immaturity of the red cells in these conditions should be borne in mind.

We are indebted to Miss Joanna Belin for carrying out the determinations of serum linoleate. We wish to thank the Multiple Sclerosis Society for their financial support and for the provision of a Perkin-Elmer F11 gas chromatograph.

\section{REFERENCES}

Baker, R. W. R., Sanders, H., Thompson, R. H. S., and Zilkha, K. J. (1965). Serum cholesterol linolente levels in multiple sclerosis. J. Neurol. Neurosurg. Psychiat., 28, 212-217.

Baker, R. W. R., Thompson, R. H. S., and Zilkha, K. J. (1964). Serum fatty acids in multiple sclerosis. $J$. Neurol. Neurosurg. Psychiat., 27, 408-414.

Baker, R. W. R., Thompson, R. H. S., and Zilkha, K. J. (1966). Changes in the amounts of linoleic acid in the serum of patients with multiple sclerosis. J. Neurol. Neurosurg. Psychiat., 29, 95-98.

Caspary, E. A., Prineas, J., Miller, H., and Field, E. J. (1965). Platelet stickiness in multiple sclerosis. Lancet, 2, 1108-1109.

Caspary, E. A., Sewell, F., and Field, E. J. (1967). Red blood cell fragility in multiple sclerosis. Brit. med.J., 2, 610-611.

Cendrowski, W., Szajbel, W., Waskiewicz, E., and Niedzielska, K. (1968). Serum lipid studies in multiple sclerosis. Z. klin. Chem., 6, 423-425.

Cohen, P., and Derksen, A. (1969). Comparison of phospholipid and fatty acid composition of human erythrocytes and platelets. Brit. J. Haemat., 17, 359-371.

Fog, T., Kristensen, I., and Helweg-Larsen, H. F. (1955). Blood platelets in disseminated sclerosis. Arch. Neurol. (Chic.), 73, 267-285.

Folch, J., Lees, M., and Sloane-Stanley, G. H. (1957). A simple method for the isolation and purification of total lipides from animal tissues. J. biol. Chem., 226, 497-509.

Hornstein, I., Crowe, P. F., and Ruck, J. B. (1967). Separation of muscle lipids into classes by nonchromatographic techniques. Anal. Chem., 39, 352-354.

Laszlo, S. (1964). Fragilité osmotique des globules rouges dans la sclérose en plaques. Acta. neurol. belg., 64, 529533.

Marcus, A. J., Ullman, H. L., and Safier, L. B. (1969). Lipid composition of subcellular particles of human blood platelets. J. Lipid Res., 10, 108-114.

Millac, P. (1967). Platelet stickiness in multiple sclerosis. Dtsch. Z. Nervenheilk., 191, 74-79. 
Millar, J. H. D., Merrett, J. D., and Dalby, A. M. (1966). Platelet stickiness in multiple sclerosis. J. Neurol. Neurosurg Psychiat., 29, 187-189.

Nathanson, M., and Savitsky, J. P. (1952). Platelet adhesive index studies in multiple sclerosis and other neurologic disorders. Bull. N. Y. Acad. Med., 28, 462-468.

Plum, C. M., and Fog, T. (1959). Studies in multiple sclerosis. Acta psychiat. scand., 34, Suppl. No. 128.

Prineas, J. (1968). Red blood cell size in multiple sclerosis. Acta neurol. scand. , 44, 81-90.

Rouser, G., O'Brien, J., and Heller, D. (1961). The separation of phosphatidyl ethanolamine and phosphatidyl serine by column chromatography. J. Amer. Oil Chem. Soc., 38, 14-19.

Rouser, G., Siakotos, A. N., and Fleischer, S. (1966). Quantitative analysis of phospholipids by thin-layer chromatography and phosphorus analysis of spots. Lipids, 1, 85-86.

Sanders, H., Thompson, R. H. S., Wright, H. P., and Zilkha, K. J. (1968). Further studies on platelet adhesiveness and serum cholesteryl linoleate levels in multiple sclerosis J. Neurol. Neurosurg. Psychiat., 31, 321-325.

Šercl, M., Kovařik, J., and Jícha, J. (1961). Étude des valeurs des lipides du sérum sanguin en cas de sclérose en plaques. Acta neurol. scand., 37, 317-324.

Tichý, J., Vymazal, J., and Michalec, C. (1969). Serum lipoproteins, cholesterol esters and phospholipids in multiple sclerosis. Acta neurol. scand., 45, 32-40.

Van Deenen, L. L. M., and de Gier, J. (1964a). Chemical composition and metabolism of lipids in red cells of various animal species. In The Red Blood Cell. Pp. 243269. Edited by C. W. Bishop and D. M. Surgenor. Academic Press: New York.

Van Deenen, L. L. M., and de Gier, J. (1964b). The Red Blood Cell. P. 300. Edited by C. W. Bishop and D. M. Surgenor. Academic Press: New York.

Ways, P., and Hanahan, D. J. (1964). Characterisation and quantification of red cell lipids in normal man. $J$. Lipid Res., 5, 318-328.

Wright, H. P. (1941). The adhesiveness of blood platelets in normal subjects with varying concentrations of anticoagulants. J. Path. Bact., 53, 255-262.

Wright, H. P., Thompson, R. H. S., and Zilkha, K. J. (1965). Platelet adhesiveness in multiple sclerosis. Lancet, 2, 1109-1110. 